\title{
Improved detection of esp, hyl, asa1, gelE, $c y \mid A$ virulence genes among clinical isolates of Enterococci
}

\author{
Alexander Kiruthiga ${ }^{1,2}$, Kesavaram Padmavathy ${ }^{1 *}$, Praveen Shabana ${ }^{3}$, Venkatesan Naveenkumar ${ }^{4}$, \\ Sumathi Gnanadesikan ${ }^{5}$ and Jeevan Malaiyan ${ }^{5}$
}

\begin{abstract}
Objective: Virulence factors (VFs) among the clinical strains of enterococci play a vital role in pathogenesis. This study was aimed to screen for cylA, asa1, gelE, esp and hyl among Enterococcus faecalis $(n=89)$ and E. faecium $(n=51)$ by multiplex PCR. The previously reported multiplex PCR was modified to 2 duplex (asa1 and gelE, cylA and esp) PCRs and 1 simplex (hyl) PCR. The idea of the modification of the multiplex PCR proposed here emerged in the course of the research study when majority of the isolates which phenotypically exhibited virulence traits were found to be negative for the respective gene.

Results: $C y / A$, gelE and asa 1 were significantly predominant in E. faecalis $(59.55 \%, 85.39 \%, 86.51 \%)$ than E. faecium $(1.96 \%, 60.78 \%, 9.80 \%)(p<0.0001, p=0.001967, p<0.0001)$. hy/ was detected in E. faecium (5.9\%) only. The number of VFs detected in each isolate was recorded as the VF score. E. faecalis isolates had a VF score pattern of score 4 (34.83\%), score $3(26.96 \%)$, score $2(28.08 \%)$ and score 1 (8.98\%) while E. faecium had score 4 (1.96\%), score 3 (7.84\%), score 2 (25.49\%) and score 1 (41.18\%). This modification of the PCR protocol could resolve the problem of decreased detection of virulence determinants in enterococci.
\end{abstract}

Keywords: E. faecalis, E. faecium, Virulence, Modified PCR reactions

\section{Introduction}

Enterococcus faecalis and E. faecium, the two most common species of enterococci that inhabit the gastrointestinal tract are a leading cause of opportunistic and nosocomial infections in humans. Pathogenesis of enterococci is attributed to an array of virulence factors (VFs) viz., aggregation substance (AS), gelatinase (Gel), cytoly$\sin (\mathrm{Cyl})$, enterococcal surface protein (Esp) and hyaluronidase ( $\mathrm{Hyl})$.

Cytolysin elaborated by hemolytic strains of $E$. faecalis contributes to virulence in animal models and in human

\footnotetext{
*Correspondence: padmabakianath@gmail.com

${ }^{1}$ Department of Microbiology, Research Laboratory for Oral and Systemic Health, Sree Balaji Dental College and Hospital, BIHER, Velachery Main Road, Chennai 600100, India

Full list of author information is available at the end of the article
}

infections [1-3]. The cytolysin operon is a two-component system, lysin (L) encoded by $c y l L 1, c y l L 2, c y l M$, $c y l B$ and an activator (A) encoded by $c y l A[4,5]$. Gelatinase encoded by gelE, is an extracellular zinc-endopeptidase/protease produced by E. faecalis that is capable of hydrolyzing gelatin, collagen, casein, hemoglobin, and other peptides [6]. Gelatinase production in E. faecalis contributes to virulence in animals and humans $[7,8]$. Gelatinase damages the host tissue facilitating bacterial migration and spread [9], colonisation and persistence by biofilm formation [10]. Enterococcal surface protein, encoded by esp, is significantly higher among clinical isolates than faecal isolates and is associated with increased virulence [11], colonization and persistence in the urinary tract [12] and biofilm formation [13]. Aggregation substance, encoded by asa1, facilitates the conjugative 
transfer of sex pheromone gene-containing plasmids [14] and enhances virulence (adherence to renal tubular cells [15], heart endocardial cells [16] and internalization by intestinal epithelial cells [17]). Hyaluronidase, encoded by the chromosomal $h y l$, is reported to be specific for $E$. faecium $[18,19]$ and shows homology to the hyaluronidases of other Gram positive cocci [20]. Esp and Hyl are known to be specific for E. faecium, while AS, Gel, Cyl, Esp for E. faecalis [18, 19].

Though phenotypic and genotypic methods are available for the detection of VFs, majority of the previous studies (Additional file1: Table S1) have adopted the multiplex PCR protocol described by Vankerckhoven et al. [18]. Nevertheless, in our experience, we found isolates which phenotypically exhibited virulence traits were found to be negative for the respective gene. In addition, non-specific amplifications were observed. Hence, this study was designed with slight modifications to the existing multiplex PCR protocol [18].

\section{Main text \\ Materials and methods}

Clinical samples were collected after obtaining approval from the Institutional Ethical Committee, Sree Balaji Dental College \& Hospital, BIHER, Chennai, India (IEC No: SBDCECM106/14/08/dt19.06.2014). A total of 140 clinical isolates of Enterococci (E. faecalis $[\mathrm{n}=89]$, E. faecium $[\mathrm{n}=51]$ from urine $[\mathrm{n}=111]$, pus $[\mathrm{n}=24]$, body fluids $[n=4]$ and blood $[n=1]$ ) from patients with urinary tract infection, pyogenic wound infection, infected body fluids, bacteraemia attending tertiary care hospitals in Chennai, South India were included in the study. Species identification and characterization was performed as per standard biochemical tests [21] and further confirmed using Enterococcus Differential Agar supplemented with 1\% 2,3,5-Triphenyl Tetrazolium Chloride (TTC) (HiMedia Laboratories Pvt Ltd, Mumbai, India).

\section{Phenotypic screening of virulence}

Hemolysin production was assessed using blood agar plates (5\% defibrinated sheep blood). A clear zone of haemolysis around enterococcal colonies after incubation at $37{ }^{\circ} \mathrm{C}$ for $24 \mathrm{~h}$ was scored positive [22]. Gelatinase production was detected by stabbing enterococcal isolates into $12 \%$ gelatin and after incubation at $37^{\circ} \mathrm{C}$ for $24 \mathrm{~h}$, positive gelatinase activity was indicated by liquefied gelatin even after refrigeration at $4{ }^{\circ} \mathrm{C}$ for $4 \mathrm{~h}$ [22]. Slime production was detected using Congo Red agar. A positive slime layer formation was indicated by black pigmented enterococcal colonies after incubation at $37^{\circ} \mathrm{C}$ for $24 \mathrm{~h}$ [23].

\section{Multiplex PCR}

DNA was extracted from overnight pure cultures of Enterococcal isolates by boiling lysis method. All Enterococci strains were screened for the presence of five VFs encoding genes (asa1, cylA, esp, gelE and $h y l$ ) using multiplex PCR as previously described [18]. Five primer pairs were used to amplify the genes asa1, gelE [18], cylA [24], esp [25] and $h y l$ [18]. All the primers used in the study were synthesised at Macrogen (South Korea). This multiplex PCR is the most commonly used protocol for screening of virulence genes among enterococci (Additional file 1: Table S1). However, in our study, a very low prevalence of the virulence determinants was detected. Isolates which phenotypically exhibited the virulence trait was found to be negative (gene not detected by the multiplex PCR protocol) for the respective gene. In addition, non-specific amplifications were observed, amplicon size were not specific to the one indicated in the reference article [18]. Hence, simplex PCR for the individual genes were performed, followed by PCR with all possible combinations of the 5 genes. Finally, the following combinations of PCR reactions were standardised.

\section{$P C R$ standardization}

Three different PCR reactions were standardised [two duplex (asa1 and gelE; cylA and esp) and one simplex (hyl) PCR]. Each $25 \mu \mathrm{l}$ PCR reaction was set up with $2 \mu \mathrm{l}$ of DNA template, $10 \times$ PCR buffer containing $15 \mathrm{mM}$ $\mathrm{MgCl}_{2}, 10 \mathrm{pmol}$ of each primer specific for the respective gene (for duplex 1: asa1, gelE, duplex 2: cylA, esp and simplex: hyl (Macrogen, Korea), $0.5 \mathrm{U}$ (for duplex 1: asa1, gelE and simplex: hyl) and $1 \mathrm{U}$ (for duplex 2: cylA, esp) of TaqDNA polymerase (Genet Bio Co, South Korea), $10 \mathrm{mM}$ of each dNTP (BioBasic, Canada Inc) and $100 \mathrm{mM} \mathrm{MgSO}_{4}$ (New England BioLabs Inc, USA).

The cycling conditions include an initial denaturation at $95{ }^{\circ} \mathrm{C}$ for $5 \mathrm{~min}$, followed by 30 cycles of denaturation $\left(94{ }^{\circ} \mathrm{C}\right.$ for $\left.1 \mathrm{~min}\right)$, annealing $\left(56^{\circ} \mathrm{C}\right.$ for $\left.1 \mathrm{~min}\right)$, and extension $\left(72{ }^{\circ} \mathrm{C}\right.$ for $\left.1 \mathrm{~min}\right)$, and a final extension for $8 \mathrm{~min}$ at $72{ }^{\circ} \mathrm{C}$. PCR was carried out in Veriti ${ }^{\mathrm{TM}}$ 96-well Thermal Cycler, Applied Biosystem, USA. Known positive and negative controls were included for each run. DNA ladder, 100-bp (GeNet Bio, South Korea) was included as a molecular size marker.

\section{DNA sequencing of virulence genes}

PCR amplicons of each gene from representative isolates were purified by FavorPrep GEL/PCR Purification kit (Favorgen, Taiwan) and sequenced by Sanger sequencing method at Macrogen (South Korea) in single directions by respective forward primer using ABI PRISM ${ }^{\circledR}$ BigDye $^{\mathrm{TM}}$ Terminator and ABI 3730XL sequencer (Applied 
Biosystems, USA). All the virulence gene sequences were compared with known sequences in NCBI Database by using BLAST analysis (http://www.ncbi.nlm.nih. gov/BLAST/) and the sequences were deposited in the NCBI GenBank database. (GenBank Accession numbers: MN398378 (asa1), MN398379 (cylA), MN398380 (hyl), MN398381 (gelE) and MN420464 (esp). These isolates were used as positive controls.

\section{Results}

\section{Virulence phenotype}

Of the 140 isolates, 58 (41.4\%) (E. faecalis $(\mathrm{n}=53)$, E. faecium $(\mathrm{n}=5))$ isolates were found to be beta-hemolytic. All the beta-hemolytic E. faecium isolates were those isolated from urine. Gelatinase was produced by 55 (39.3\%) isolates (E. faecalis $(\mathrm{n}=33)$, E. faecium $(\mathrm{n}=22))$. Slime production was detected in $130(92.8 \%)$ isolates (E. faecalis $(\mathrm{n}=82)$, E. faecium $(\mathrm{n}=48))$.

\section{Virulence genotype}

Among the 5 virulence determinants screened, asa 1 were significantly more common in E. faecalis followed by gelE, while, gelE was the most common gene followed by esp in E. faecium. cylA, gelE and asa1 were significantly more common in E. faecalis (59.55\%, 85.39\%, 86.51\%) than E. faecium $(1.96 \%, 60.78 \%, 9.80 \%) \quad(\mathrm{p}<0.0001$, $\mathrm{p}=0.001967, \mathrm{p}<0.0001)$. hyl was detected only in $E$. faecium $(5.9 \%)$ and not in E. faecalis $(0 \%)(\mathrm{p}=0.0465)$. However, no difference was observed in the incidence of esp between species ((E. faecalis $(53.93 \%)$ vs. E. faecium (45.09\%), $\mathrm{p}=0.406164)$.

\section{Correlation between virulence phenotype and genotype}

Among the 53 beta-hemolytic E. faecalis isolates, 48 (90.6\%) harboured the cylA gene. Among the E. faecalis isolates, 33/33 (100\%) gelatinase producers and 43/56 (77.8\%) non-gelatinase producers harboured gelE. Among
E. faecium isolates, 14/22 (63.6\%) gelatinase producers and 17/29 (58.6\%) non-gelatinase producers harboured the gelE. Among the E. faecalis $(\mathrm{n}=82)$ isolates that were slime producers, $45(54.9 \%)$ and $73(89.02 \%)$ harboured esp and asa 1 while, 3 (42.9\%), 4 (57.1\%) of the non-slime producers $(\mathrm{n}=7)$ possessed esp and asa1 respectively. Among the E. faecium isolates, 22/48 (45.8\%), 4/48 (8.3\%) of the slime producers and $1 / 3(33.3 \%), 1 / 3(33.3 \%)$ of the non-slime producers harboured the genes, esp and asa 1 respectively (Table 1).

\section{Virulence score}

Majority of the E. faecalis isolates causing UTI elaborated VFs compared to E. faecium ( $p<0.0001, \mathrm{OR}=163.3333$, 95\% CI 20.2715-1316.0268) (Table 2). The number of VFs detected in each isolate was recorded as the VF score. Majority of the E. faecalis isolates had a VF score 4 (34.83\%), followed by score 3 (26.96\%), score 2 (28.08\%), score $1(8.98 \%)$ and score $0(1.12 \%)$. Nevertheless, the VF score pattern exhibited by E. faecium was found to be in the reverse order: VF score $4(1.96 \%)$, followed by score 3 (7.84\%), score 2 (25.49\%), score $1(41.18 \%)$ and score 0 (23.53\%) (Table 2). VF score 4 and 3 were quite common among E. faecalis than E. faecium $(\mathrm{p}<0.0001,0.0124)$ respectively. Nevertheless, VF score 1 was significantly associated with E. faecium $(<0.0001)$ (Table 3).

\section{Discussion}

In our study, 39.3\% of enterococci (E. faecalis (37.1\%), E. faecium $(43.1 \%)$ ) were gelatinase producers. Our results are in concordance with previous Indian studies that have documented a lower incidence of gelatinase production in Enterococci [26, 27]. Recent studies have reported an incidence of $\mathrm{gelE}$ in the range of 31-91.4\% (Additional file 1: Table S1). Our molecular studies indicated that gelE was the second most common (76.4\%) VF detected in enterococci, more commonly in E. faecalis $(85.39 \%)$

Table 1 Correlation between virulence phenotype and genotype

\begin{tabular}{|c|c|c|c|c|c|c|c|c|}
\hline \multirow{2}{*}{$\begin{array}{l}\text { Virulence factors } \\
\text { (encoding gene) }\end{array}$} & \multicolumn{4}{|c|}{ E. faecalis $(n=89)$} & \multicolumn{4}{|c|}{ E. faecium $(n=51)$} \\
\hline & $\mathrm{P}+\mathrm{G}+$ & $P-G+$ & $P+G-$ & $P-G-$ & $\mathrm{P}+\mathrm{G}+$ & $P-G+$ & $P+G-$ & $\mathrm{P}-\mathrm{G}-$ \\
\hline Cytolysin (cylA) & 48 & 5 & 5 & 31 & 0 & 1 & 5 & 45 \\
\hline Gelatinase (gelE) & 33 & 43 & 0 & 13 & 14 & 17 & 8 & 12 \\
\hline \multicolumn{9}{|l|}{ Slime } \\
\hline asal & 73 & 4 & 9 & 3 & 4 & 1 & 44 & 2 \\
\hline esp & 45 & 3 & 37 & 4 & 22 & 1 & 26 & 2 \\
\hline
\end{tabular}

$\mathrm{P}+$ phenotypically expressed

$\mathrm{P}$ - phenotypically not expressed

$\mathrm{G}+$ Gene detected

G- Gene not detected 
Table 2 Correlation of the virulence score of the enterococci with clinical source

\begin{tabular}{|c|c|c|c|c|c|}
\hline Virulence factor score & Species & $\begin{array}{l}\text { Urine } \\
(n=111)\end{array}$ & $\begin{array}{l}\text { Pus } \\
(n=24)\end{array}$ & $\begin{array}{l}\text { Blood } \\
(n=1)\end{array}$ & $\begin{array}{l}\text { Fluid } \\
(n=4)\end{array}$ \\
\hline \multirow{2}{*}{$\begin{array}{l}\text { VF score } 5 \\
(n=0)\end{array}$} & E. faecalis $(n=0)$ & 0 & 0 & 0 & 0 \\
\hline & $\begin{array}{l}\text { E. faecium } \\
(n=0)\end{array}$ & 0 & 0 & 0 & 0 \\
\hline \multirow[t]{2}{*}{$\begin{array}{l}\text { VF score } 4 \\
(n=32)\end{array}$} & $\begin{array}{l}\text { E. faecalis } \\
(n=31)\end{array}$ & 23 & 8 & 0 & 0 \\
\hline & $\begin{array}{l}\text { E. faecium } \\
(n=1)\end{array}$ & 1 & 0 & 0 & 0 \\
\hline \multirow[t]{2}{*}{$\begin{array}{l}\text { VF score } 3 \\
(n=28)\end{array}$} & $\begin{array}{l}\text { E. faecalis } \\
(n=24)\end{array}$ & 20 & 2 & 1 & 1 \\
\hline & $\begin{array}{l}\text { E. faecium } \\
(n=4)\end{array}$ & 3 & 1 & 0 & 0 \\
\hline \multirow[t]{2}{*}{$\begin{array}{l}\text { VF score } 2 \\
(n=38)\end{array}$} & $\begin{array}{l}\text { E. faecalis } \\
(n=25)\end{array}$ & 21 & 4 & 0 & 0 \\
\hline & $\begin{array}{l}\text { E. faecium } \\
(n=13)\end{array}$ & 8 & 4 & 0 & 1 \\
\hline \multirow[t]{2}{*}{$\begin{array}{l}\text { VF score } 1 \\
(n=29)\end{array}$} & $\begin{array}{l}\text { E. faecalis } \\
(n=8)\end{array}$ & 6 & 2 & 0 & 0 \\
\hline & $\begin{array}{l}\text { E. faecium } \\
(n=21)\end{array}$ & 16 & 3 & 0 & 2 \\
\hline \multirow[t]{2}{*}{$\begin{array}{l}\text { VF score } 0 \\
(n=13)\end{array}$} & $\begin{array}{l}\text { E. faecalis } \\
(n=1)\end{array}$ & 1 & 0 & 0 & 0 \\
\hline & $\begin{array}{l}\text { E. faecium } \\
(n=12)\end{array}$ & 12 & 0 & 0 & 0 \\
\hline
\end{tabular}

Table 3 Comparison of VF scores between E. faecalis vs E. faecium

\begin{tabular}{|c|c|c|c|c|c|}
\hline Virulence score & $\begin{array}{l}\text { E. faecalis } \\
(\mathrm{n}=89)\end{array}$ & $\begin{array}{l}\text { E. faecium } \\
(n=51)\end{array}$ & $p$ value & OR & $95 \% \mathrm{Cl}$ \\
\hline $\begin{array}{l}\text { VF score } 5 \\
(n=0)\end{array}$ & $0(0 \%)$ & $0(0 \%)$ & $1^{*}$ & - & - \\
\hline $\begin{array}{l}\text { VF score } 4 \\
(n=32)\end{array}$ & 31 (34.83\%) & $1(1.96 \%)$ & $<0.0001^{*}$ & 26.7241 & $3.5205-202.8634$ \\
\hline $\begin{array}{l}\text { VF score } 3 \\
(n=28)\end{array}$ & $24(26.96 \%)$ & 4 (7.84\%) & $0.0124^{*}$ & 4.3385 & $1.4112-13.3377$ \\
\hline $\begin{array}{l}\text { VF score } 2 \\
(n=38)\end{array}$ & $25(28.08 \%)$ & $13(25.49 \%)$ & $0.888^{*}$ & 1.1418 & $0.5228-2.4939$ \\
\hline $\begin{array}{l}\text { VF score } 1 \\
(n=29)\end{array}$ & $8(8.98 \%)$ & $21(41.18 \%)$ & $<0.0001^{*}$ & 0.1411 & $0.0565-0.3525$ \\
\hline $\begin{array}{l}\text { VF score } 0 \\
(n=13)\end{array}$ & $1(1.12 \%)$ & $12(23.53 \%)$ & $0.000^{*}$ & 0.0369 & $0.0046-0.294$ \\
\hline $\begin{array}{l}\text { VF score* } \\
\text { Mean } \pm S D\end{array}$ & $2.854 \pm 1.040$ & $1.235 \pm 0.971$ & $<0.0001^{* *}$ & - & - \\
\hline
\end{tabular}

* Mann-Whitney $\mathrm{U}$ test: comparison of VF scores between E. faecalis vs. E. faecium

** Student's t test: comparison of 2 means

than E. faecium (60.78\%). Among the E. faecalis studied, all the gelatinase producers $(100 \%)$ harboured gelE gene while, the reverse was not true. In contrary, $63.6 \%$ of the gelatinase producing $E$. faecium isolates harboured gelE gene. In concordance with previous reports, gelE was present as a silent gene in E. faecalis $(77.8 \%)$, and E. faecium $(58.6 \%)[18,28]$.

In line with previous reports, $41.43 \%$ of our enterococcal isolates were beta-hemolytic $[26,27,29]$. In our study, of the beta-hemolytic enterococci (41.43\%), majority were E. faecalis (91.38\%) while, only $8.62 \%$ were E. faecium isolates. Our results corroborate with 
previous reports that document a very low frequency of cylA among E. faecium compared to E. faecalis (Additional file 1: Table S1) Of note, all the beta-hemolytic E. faecium were urinary isolates that did not harbour the gene cylA. Nevertheless, majority (90.57\%) of the beta-hemolytic E. faecalis (urine (71.7\%), pus (16.98\%), blood (1.89\%)) harboured the cylA gene. This finding is of clinical significance as the frequency of death is five times higher in an enterococcal infection associated with cytolysin-producing strain compared to a non cytolysin-producing strain [30]. In our study, cylA was present as a silent gene in $13.88 \%, 2.17 \%$ of E. faecalis and E. faecium respectively.

Esp encoded by esp is associated with adhesion, colonisation and host immune evasion. Though previous reports suggest that esp is more common in E. faecium, in our study, incidence of esp was slightly higher in $E$. faecalis (53.93\%) than E. faecium (45.09\%) [31, 32]. The incidence of esp and asa1 shows a wide variation in various reports (Additional file 1: Table S1). Among the slime producers, $54.9 \%, 89.02 \%$ of $E$. faecalis isolates, and $45.8 \%, 8.3 \%$ of E. faecium harboured esp and asa1 respectively. In our study, esp and asa1 were found to be silent genes in both E. faecium (33.3\%, 33.3\%) and $E$. faecalis isolates $(42.9 \%, 57.1 \%)$. As reported earlier, $h y l$ was detected only in E. faecium [33]. Nevertheless, a few studies have reported the incidence of hyl in both species $[29,34-39]$. Significant difference was observed in the VF score between species. In line with previous studies, E. faecalis $(61.8 \%)$ were found to be multi-virulent with VF Scores 4 or 3 while, VF score 1 was quite common in E. faecium $(41.18 \%)$ [27, 36]. Majority of the urinary $E$. faecalis elaborated multiple VFs compared to E. faecium.

Non-expression of these virulence genes could be attributed to a triad of factors, (i) gene expression is triggered in late exponential phase at high cell densities, (ii) environmental factors might influence gene expression and (iii) in vitro phenotypic testing conditions are different from the in vivo conditions $[28,40]$. Nevertheless, the presence of virulence determinants in the clinical isolates might contribute to increased severity as they could be expressed under optimum conditions in vivo. Metadata of the previous studies on the detection of virulence genes of enterococci by multiplex/duplex/simplex PCR is depicted in Additional file 1: Table S1 [18, 27, 29, 33-39, 41-59].

\section{Conclusion}

We report that our simple modification of the existing multiplex PCR had increased the detection of the enterococcal virulence genes. Predominance of virulence genes was in order of $\operatorname{gelE}(76.43 \%)>$ asal $(58.57 \%)>$ esp $(50.71 \%)>c y l A$ $(38.57 \%)>h y l(2.14 \%)$. Virulence determinants were more common in E. faecalis (asa1 (86.51\%), gelE (85.39\%), cylA (59.55\%)) than E. faecium (asa1 (9.80\%), gelE (60.78\%), cylA (1.96\%)). hyl was detected only in E. faecium. This modified PCR protocol could be useful to resolve the problem of decreased detection of virulence determinants in enterococci.

\section{Limitations of the study}

This study lacks the analysis of other virulence factors elaborated by enterococci. Also, majority of the study isolates were from urine with very less number from other body fluids.

\section{Supplementary information}

Supplementary information accompanies this paper at https://doi. org/10.1186/s13104-020-05018-0.

Additional file 1. Metadata.

Abbreviations

AS: Aggregation substance; Cyl: Cytolysin; Esp: Enterococcal surface protein; Gel: Gelatinase; Hyl: Hyaluronidase; PCR: Polymerase chain reaction.

\section{Acknowledgements}

We would like to thank the Department of Science \& Technology, India for the instrumentation facility provided through Fund for Improvement of Science \& Technology (FIST) (SR/FST/College -2017/23).

\section{Authors' contributions}

Conceptualisation: KP and VN, Experimentation: AK, KP, Supervision: VN, PS, Sample collection: SG, JM, Writing original draft: AK, KP. Review and editing: VN, PS, SG, JM. All authors read and approved the final manuscript.

\section{Funding}

This research work was not funded by any organisation.

Availability of data and materials

GenBank Accession numbers: MN398378 (asa1), MN398379 (cylA), MN398380 (hyl), MN398381 (gelE) and MN420464 (esp).

\section{Ethics approval and consent to participate}

This research work has been reviewed and approved by the Institutional Ethical Committee, Sree Balaji Dental College \& Hospital, BIHER, Chennai, India (IEC No: SBDCECM106/14/08/dt19.06.2014).

\section{Consent to publish}

Not applicable.

\section{Competing interests}

The authors declare they have no competing interests.

\section{Author details}

${ }^{1}$ Department of Microbiology, Research Laboratory for Oral and Systemic Health, Sree Balaji Dental College and Hospital, BIHER, Velachery Main Road, Chennai 600100, India. ${ }^{2}$ Department of Microbiology, Priyadarshini Dental College and Hospital, Pandur, Thiruvallur, India. ${ }^{3}$ Department of Laboratory Medicine, Meitra Hospital, Calicut, India. ${ }^{4}$ ImmuGenix Biosciences Pvt Ltd, Chennai, India. ${ }^{5}$ Department of Microbiology, Sri Muthukumaran Medical College Hospital and Research Institute, Chennai, India.

Received: 28 November 2019 Accepted: 13 March 2020 Published online: 20 March 2020 


\section{References}

1. Chow JW, Thal LA, Perri MB, Vazquez JA, Donabedian SM, Clewell DB, Zervos MJ. Plasmid-associated hemolysin and aggregation substance production contribute to virulence in experimental enterococcal endocarditis. Antimicrob Agents Chemother. 1993:37:2474-7.

2. Jett BD, Jensen HG, Nordquist RE, Gilmore MS. Contribution of the pAD1encoded cytolysin to the severity of experimental Enterococcus faecalis endophthalmitis. Infect Immun. 1992;60:2445-52.

3. Ike $\mathrm{Y}$, Hashimoto $\mathrm{H}$, Clewell DB. High incidence of hemolysin production by Enterococcus (Streptococcus) faecalis strains associated with human parenteral infections. J Clin Microbiol. 1987;25:1524-8.

4. Gilmore MS, Segarra RA, Booth MC. An HlyB-type function is required for expression of the Enterococcus faecalis hemolysin/bacteriocin. Infect Immun. 1990:58:3914-23.

5. Ike Y, Clewell DB, Segarra RA, Gilmore MS. Genetic analysis of the pAD1 hemolysin/bacteriocin determinant in Enterococcus faecalis: Tn917 insertional mutagenesis and cloning. J Bacteriol. 1990;172:155-63.

6. Su YA, Sulavik MC, He P, Makinen KK, Makinen PL, Fiedler S, Wirth R, Clewell DB. Nucleotide sequence of the gelatinase gene (gelE) from Enterococcus faecalis subsp liquefaciens. Infect Immun. 1991:59:415-20.

7. Gutschik E, Moller S, Christensen N. Experimental endocarditis in rabbits. Significance of the proteolytic capacity of the infecting strains of Streptococcus faecalis. Acta Pathol Microbiol Scand. 1979;87:353-62.

8. Coque TM, Steckelberg JM, Patterson JE, Murray BE. Possible virulence factors of enterococci. 1993; abstr. 1166. Program Abstr. 33rd Intersci. Conf. Antimicrob Agents Chemother.

9. Franz CMAP, Huch M, Abriouel H, Holzapfeland W, Gálvez A. Enterococci as probiotics and their implications in food safety. Int J Food Microbiol. 2011;151(2):125-40

10. Del Papa MF, Hancock LE, Tomas VC, Perego M. Full activation of Enterococcus faecalis gelatinase by a $\mathrm{C}$ terminal proteolytic cleavage. J Bacteriol. 2007;189(24):8835-43.

11. Shankar V, Baghdayan AS, Huycke MM, Lindahl G, Gilmore MS. Infectionderived Enterococcus faecalis strains are enriched in esp, a gene encoding a novel surface protein. Infect Immun. 1999;67:193-200.

12. Shankar N, Lockatell CV, Baghdayan AS, Drachenberg C, Gilmore MS, Johnson DE. Role of Enterococcus faecalis surface protein, Esp in the pathogenesis of ascending urinary tract infection. Infect Immun. 2001;69:4366-72

13. Toledo-Arana A, Valle J, Solano C, Arrizubieta MJ, Cucarella C, Lamata M, Amorena B, Leiva J, Penades JR, Lasa I. The enterococcal surface protein, Esp, is involved in Enterococcus faecalis biofilm formation. Appl Environ Microbiol. 2001;67:4538-45.

14. Galli D, Lottspeich F, Wirth R. Sequence analysis of Enterococcus faecalis aggregation substance encoded by the sex pheromone plasmid PAD1. Mol Microbiol. 1990;4:895-904.

15. Kreft B, Marre R, Schramm U, Wirth R. Aggregation substance of Enterococcus faecalis mediates adhesion to cultured renal tubular cells. Infect Immun. 1992;60:25-30.

16. Guzman CA, Pruzzo C, LiPira G, Calegari L. Role of adherence in pathogenesis of Enterococcus faecalis urinary tract infection and endocarditis. Infect Immun. 1989;57:1834-8.

17. Olmsted SB, Dunny GM, Erlandsen SL, Wells CL. A plasmid-encoded surface protein on Enterococcus faecalis augments its internalization by cultured intestinal epithelial cells. J Infect Dis. 1994;170:1549-56.

18. Vankerckhoven V, Van Autgaerden T, Vael C, Lammens C, Chapelle S, Rossi $\mathrm{R}$, Jabes D, Goossens H. Development of a multiplex PCR for the detection of asal, gelE, cylA, esp, and hyl genes in enterococci and survey for virulence determinants among European hospital isolates of Enterococcus faecium. J Clin Microbiol. 2004;42(10):4473-9.

19. Rice LB, Carias L, Rudin S, Vael C, Goossens H, Konstable C, Clare I, Nallapareddy SR, Huang W, Murray BE. A potential virulence gene, hylE $E_{f m}$ predominates in Enterococcus faecium of clinical origin. J Infect Dis. 2003;187:508-12.

20. Hynes WL, Walton SL. Hyaluronidases of gram-positive bacteria. FEMS Microbiol Lett. 2000;183:201-7.

21. Facklam RR, Collins MD. Identification of Enterococcus species isolated from human infections by a conventional test scheme. J Clin Microbiol. 1989;27(4):731-4.

22. Fernandes SC, Dhanashree B. Drug resistance \& virulence determinants in clinical isolates of Enterococcus species. Indian J Med Res. 2013;137:981-5.
23. Freeman DJ, Falkiner FR, Keane CT. New method for detecting slime production by coagulase negative Staphylococci. J Clin Pathol. 1989;42(8):872-4

24. Coque TM, Patterson JE, Steckelberg JM, Murray BE. Incidence of hemolysin, gelatinase, and aggregation substance among enterococci isolated from patients with endocarditis and other infections and from feces of hospitalized and community-based persons. J Infect Dis. 1995; 171:1223-9.

25. Willems RJ, Homan W, Top J, Santen-Verheuvel M, Tribe D, Manzioros X, Gaillard C, Vandenbroucke-Grauls CM, Mascini EM, Van Kregten E, Van Embden JD, Bonten MJ. Variant esp gene as a marker of a distinct genetic lineage of vancomycin-resistant Enterococcus faecium spreading in hospitals. Lancet. 2001;357:853-5.

26. Ravichandran L, Sivaraman U, Pramodhini S, Srirangaraj S, Seetha KS. Prevalence of virulence factors among clinical isolates of Enterococcus spp. Asian J Pharm clin Res. 2016;9(9):72-5.

27. Padmasini E, Divya G, Karkuzhali M, Padmaraj R, Srivani Ramesh S. Distribution of cylA, esp, asa 1, hyl and gelE virulence genes among clinical isolates of Enterococcus faecium and Enterococcus faecalis. BMC Infect Dis. 2014;14(S3):P32.

28. Eaton TJ, Gasson MJ. Molecular screening of Enterococcus virulence determinants and potential for genetic exchange between food and medical isolates. Appl Environ Microbiol. 2001;67:1628-35.

29. Banerjee T, Anupurba S. Prevalence of virulence factors and drug resistance in clinical isolates of Enterococci: a study from North India. J Pathog. 2015;2015:692612.

30. Huycke MM, Spiegel CA, Gilmore MS. Bacteremia caused by hemolytic, high-level gentamicin-resistant Enterococcus faecalis. Antimicrob Agents Chemother. 1991;35(8):1626-34.

31. Tendolkar PM, Baghdayan AS, Shankar N. Pathogenic enterococci: new developments in the 21st century. Cell Mol Life Sci. 2003;60(12):2622-36.

32. Araújo TF, Ferreira CLDLF. The genus enterococcus as probiotic: safety concerns. Braz Arch Biol Technol. 2013;56(3):457-66.

33. Dogru AK, Gencay YE, Ayaz ND. Comparison of virulence gene profiles of Enterococcus faecium and Enterococcus faecalis chicken neck skin and faeces isolates. Kafkas Üniversitesi Veteriner Fakültesi Dergisi. 2010;16:129-33.

34. Biswas PP, Dey S, Sen A, Adhikari L. Molecular characterization of virulence genes in vancomycin-resistant and vancomycin-sensitive enterococci. J Glob Infect Dis. 2016;8(1):16-24.

35. Ferguson DM, Talavera GN, Hernández LA, Weisberg SB, Ambrose RF, Jay JA. Virulence Genes among Enterococcus faecalis and Enterococcus faecium isolated from coastal beaches and human and non-human sources in Southern California and Puerto Rico. J Pathog. 2016;2016:3437214.

36. Strateva T, Atanasova D, Savov E, Petrova G, Mitov I. Incidence of virulence determinants in clinical Enterococcus faecalis and Enterococcus faecium isolates collected in Bulgaria. Braz J Infect Dis. 2016;20(2):127-33.

37. Heidari H, Hasanpour S, Ebrahim-Saraie HS, Motamedifar M. High incidence of virulence factors among clinical Enterococcus faecalis isolates in Southwestern Iran. Infect Chemother. 2017;49(1):51-6.

38. Shokoohizadeh L, Ekrami A, Labibzadeh M, Ali L, Alavi SM. Antimicrobial resistance patterns and virulence factors of enterococci isolates in hospitalized burn patients. BMC Res Notes. 2018;11:1.

39. Golob M, Pate M, Kušar D, Dermota U, Avberšek J, Papic B, Zdovc I. Antimicrobial Resistance and virulence genes in Enterococcus faecium and Enterococcus faecalis from humans and retail red meat. BioMed Res Int. 2019;2019:2815279.

40. Finlay BB, Falkow S. Common themes in microbial pathogenicity revisited Microbiol Mol Biol Rev. 1997;61(2):136-69.

41. Billström H, Lund B, Sullivan A, Nord CE. Virulence and antimicrobial resistance in clinical Enterococcus faecium. Int J Antimicrob Agents. 2008:32(5):374-7.

42. Martín-Platero AM, Valdivia E, Maqueda M, Martínez-Bueno M. Characterization and safety evaluation of enterococci isolated from Spanish goats' milk cheeses. Int J Food Microbiol. 2009;132:24-32.

43. Zoletti GO, Pereira EM, Schuenck RP, Teixiera LM, Siqueira JF Jr, dos Santos KR. Characterization of virulence factors and clonal diversity of Enterococcus faecalis isolates from treated dental root canals. Res Microbiol. 2011;162(2):151-8.

44. Ribeiro T, Oliveira M, Fraqueza MJ, Lauková A, Elias M, Tenreiro R, Barreto AS, Semedo-Lemsaddek T. Antibiotic resistance and virulence factors 
among Enterococci isolated from chouriço, a traditional Portuguese dry fermented sausage. J Food Prot. 2011;74(3):465-9.

45. Hasani A, Sharifi Y, Ghotaslou R, Naghili B, Hasani A, Aghazadeh M, Milan $M$, Bazmani A. Molecular screening of virulence genes in high-level gentamicin resistant Enterococcus faecalis and Enterococcus faecium isolated from clinical specimens in North west Iran. Indian J Med Microbiol. 2012;30(2):175-81.

46. Medeiros AW, Pereira RI, Oliveira DV, Martins PD, d'Azevedo PA, Van der Sand S, Frazzon J, Frazzon AP. Molecular detection of virulence factors among food and clinical Enterococcus faecalis strains in South Brazil. Braz J Microbiol. 2014;45(1):327-32.

47. Abdeen EE, Hussien H, Hussan Z, Abdella W. Genotyping and virulence genes of Enterococcus faecalis Isolated form Kareish cheese and minced meat in Egypt. Res J Microbiol. 2016;11:133-8.

48. Tuhina B, Anupurba S, Karuna T. Emergence of antimicrobial resistance and virulence factors among the unusual species of enterococci, from North India. Indian J Pathol Microbiol. 2016;59:50-5.

49. Wu X, Hou S, Zhang Q, Ma Y, Zhang Y, Kan W, Zhao X. Prevalence of virulence and resistance to antibiotics in pathogenic enterococci isolated from mastitic cows. J Vet Med Sci. 2016:78(11):1663-8.

50. Zheng JX, Wu Y, Lin ZW, Pu ZY, Yao WM, Chen Z, Li DY, Deng QW, Qu D, Yu ZJ. Characteristics of and virulence factors associated with biofilm formation in clinical Enterococcus faecalis isolates in China. Front Microbiol. 2017:24(8):2338.

51. Kashef M, Alvandi A, Hasanvand B, Azizi M, Abiri R. Virulence factor and biofilm formation in clinical enterococcal isolates of the West of Iran. Jundishapur J Microbiol. 2017;10(7):e14379.

52. Yang F, Zhang S, Shang X, Wang X, Yan Z, Li H, Li J. Short communication: antimicrobial resistance and virulence genes of Enterococcus faecalis isolated from subclinical bovine mastitis cases in China. J Dairy Sci. 2019;102(1):140-4.
53. Pillay S, Zishiri OT, Adeleke MA. Prevalence of virulence genes in Enterococcus species isolated from companion animals and livestock. Onderstepoort J Vet Res. 2018;85(1):e1-8.

54. Song H, Bae Y, Jeon E, Kwon Y, Joh S. Multiplex PCR analysis of virulence genes and their influence on antibiotic resistance in Enterococcus spp. isolated from broiler chicken. J Vet Sci. 2019;20(3):e26.

55. Aladarose BE, Said HS, Abdelmegeed ES. Incidence of virulence determinants among enterococcal clinical isolates in egypt and its association with biofilm formation. Microb Drug Resist. 2019;6:880-9.

56. Haghi F, Lohrasbi V, Zeighami H. High incidence of virulence determinants, aminoglycoside and vancomycin resistance in enterococci isolated from hospitalized patients in Northwest Iran. BMC Infect Dis. 2019;19(1):744.

57. Shridhar S, Dhanashree B. Antibiotic Susceptibility Pattern and Biofilm Formation in Clinical Isolates of Enterococcus spp. Interdiscip Perspect Infect Dis. 2019;3:7854968.

58. Mohanty S, Behera B, Praharaj AK. Identification, antimicrobial susceptibility and virulence factors of Enterococcus species isolated from clinical specimens at an Indian tertiary care hospital. Int J Infect Dis. 2019:79(S1):49

59. Stępień-Pyśniak D, Hauschild T, Kosikowska U, Dec M, Urban-Chmiel R. Biofilm formation capacity and presence of virulence factors among commensal Enterococcus spp. from wild birds. Sci Rep. 2019;9(1):11204.

\section{Publisher's Note}

Springer Nature remains neutral with regard to jurisdictional claims in published maps and institutional affiliations.
Ready to submit your research? Choose BMC and benefit from:

- fast, convenient online submission

- thorough peer review by experienced researchers in your field

- rapid publication on acceptance

- support for research data, including large and complex data types

- gold Open Access which fosters wider collaboration and increased citations

- maximum visibility for your research: over $100 \mathrm{M}$ website views per year

At BMC, research is always in progress.

Learn more biomedcentral.com/submissions 